\title{
Spectrophotometric Method for Determination of Chloramphenicol in Pharmaceutical Preparations using o-Chloranil Reagent
}

Thabit S.Al-Ghabsha Theia'a N.Al-Sabha Mohammed S.Al-Enizzi Chemistry Department, College of Education, Mosul University, Mosul, Iraq

\section{الخلاصة}

تم وصف طريقة طيفية سهلة وحساسـة لتقدير الكلورامفينيكول بثكله النقي وفي

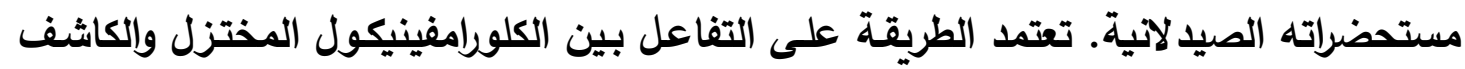

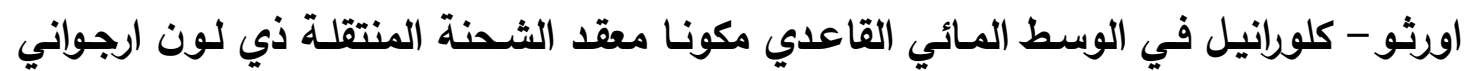

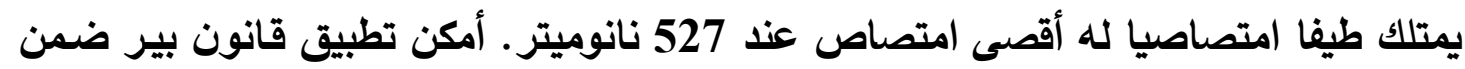

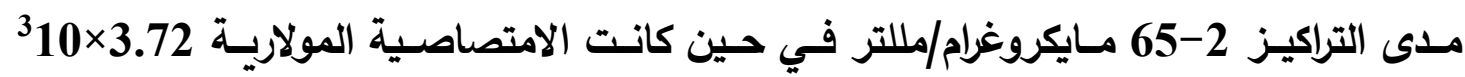

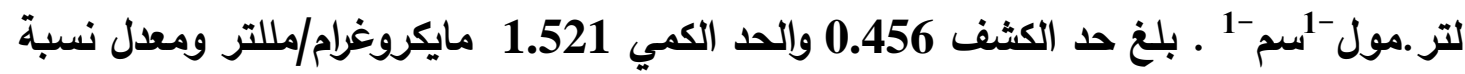
الاسترجاع 100.9\% في حين كان ألاتحراف القياسي النسبي أفضل من 2.2.

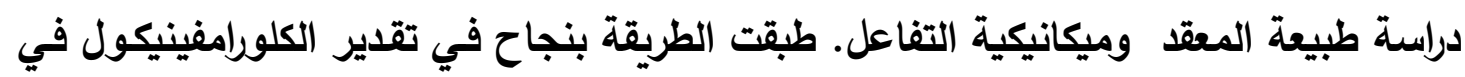
مستحضراته الصيدلانية بشكل كبسول وقطرة العين بدقة وتوافق جيدين. كما تم مقارنة الطريقة المقترحة مع الطريقة القياسية في الاستور البريطاني وطرائق طيفية أخرى.

\section{ABSTRACT}

A simple, sensitive and rapid spectrophotometric method for the determination of chloramphenicol in pure as well as in dosage form is described. The method is based on the reaction of reduced chloramphenicol with o-chloranil in an aqueous alkaline medium to form a purple colored charge transfer complex of maximum absorption peak at $527 \mathrm{~nm}$. Under the optimized reaction conditions, Beer's law correlating the absorbance with chloramphenicol concentration was obeyed in the range of $2-65 \mu \mathrm{g} \mathrm{ml}^{-1}$ with molar absorptivity $3.72 \times 10^{3} \mathrm{~L} \mathrm{~mol}^{-1} \mathrm{~cm}^{-1}$. The limits of detection and quantitation were 0.456 and $1.521 \mu \mathrm{g} \mathrm{ml}^{-1}$, respectively. 
The accuracy and precision of the method were satisfactory; the average recovery was $100.9 \%$ and values of relative standard deviations better than $2.2 \%$. The stoichiometry of the reaction was studied, and the reaction mechanism was postulated. The proposed method was successfully applied to the determination of chloramphenicol in its pharmaceutical capsule and eye drops with good accuracy and precisions. The results obtained by the proposed method are compared with those obtained by the official method and other reported methods.

Keywords: Spectrophotometry; Chloramphenicol; o-Chloranil; Pharmaceutical preparations.

\section{INTRODUCTION}

Chloramphenicol [2,2-dichloro-N- $[(1 \mathrm{R}, 2 \mathrm{R} \quad-2-$ hydroxyl - 1 (hydroxymethyl)-2-(4-nitrophenyl)ethyl] acetamide], (Scheme 1), is a broad-spectrum antibiotic active against Gram-positive and Gramnegative bacteria. It is produced naturally by the soil bacterium Streptomyces Venezuelan, but is presently mainly produced by chemical synthesis [1-3]. It has been used in veterinary practice for prevention and treatment of many bacterial infections because of its efficiency, easy availability and low cost $[4,5]$. Moreover, Due to its genotoxic effect and severe side effects, such as anemia, leucopenia, agranulocytosis and a plastic anemia in some people, its use is limited to the therapy of serious infections (e.g. typhoid fever and meningitis). Furthermore, its use in food production, such as aquaculture farming, has been banned worldwide [1,6]. Various analytical methods have been used for the determination of Chloramphenicol, which include official method $[7,8]$, chromatography $[9,10]$, ion-selective electrode technique [11], chemiluminescence $[12,13]$, titrimetry $[14,15]$, electrochemical techniques [16], flow-injection biamperometric method [17], atomic absorption spectrometry [18]. Many Spectrophotometric methods, depending on reduction of nitro group, have been reported for determination of chloramphenicol using various reagents such as isonicotinic acid hydrazide [19], $\mathrm{N}$-(1-naphthyl)ethylenediamine[20], trisodium pentacyanoaminoferrate [21], Ninhydrin [22], iminodibenzyl, 3-aminophenol, pyrocatechol and molybdate [23], orthogonal polynomials [24], ammonium molybdate [25] and pdimethylaminobenzaldehyde [26]. However; some of these methods suffer from disadvantages such as low sensitivity and narrow range of determination, tedious and needing extraction, using organic medium, and either require a long time for stable color development or exhibit instability of the colored product. Charge transfer complex formation reactions have been applied for sensitive spectrophotometric 
determination of chloramphenicol using p-chloranil [27], pfluoranil [27] and TCNQ [28] reagents as $\pi$-acceptors. The aim of the present work is to provide simple, sensitive, selective and rapid spectrophotometric method for determining of chloramphenicol in pure form as well as in pharmaceutical preparations depending on the charge transfer complex formation reaction using o-chloranil as $\pi$-acceptor .

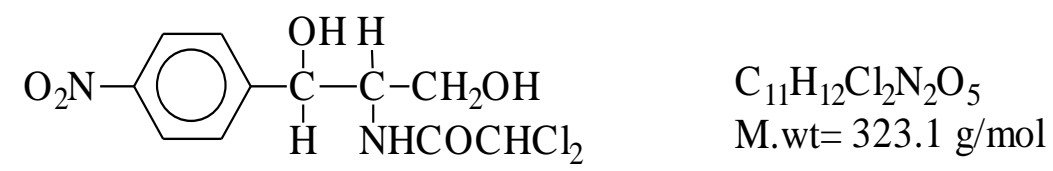

\section{Scheme 1: Chemical structure of chloramphenicol}

\section{EXPERIMENTAL}

\section{Apparatus}

All absorption measurements were made on a Shimadzu UV-210A double - beam spectrophotometer supplied with a digital printer DP80Z and matched 1-cm optical silica cells. Heating of solutions was carried out on a water bath of frost instruments, LTD. The reading of $\mathrm{pHs}$ made on a PW $9420 \mathrm{pH}$ meter supplied with an electrode type CE 10-12 pH. Weighing was carried out on a balance type of Mettler H 54 AR.

\section{Chemicals}

Chloramphenicol and its pharmaceutical formulations (capsule and eye drops) were kindly provided by state company for Drug Industries and Medical appliance-(SDI) Sammara-Iraq. o-Chloranil was obtained from MOLEKULA and other chemicals were obtained from Fluka and BDH companies. All solvents were analytical reagent grade and water was distilled.

Standard solution: $500 \mu \mathrm{g} \mathrm{m} \mathrm{m}^{-1}$ reduced chloramphenicol (RCAP) solution was prepared by dissolving of $50 \mathrm{mg}$ of its pure form in $10 \mathrm{ml}$ of distilled water and was reduced using $4 \mathrm{~g}$ zinc powder and $20 \mathrm{ml}$ of conc. hydrochloric acid and kept for $15 \mathrm{~min}$ with stirring for complete reduction. The reduced solution was filtered and diluted with water to 100 $\mathrm{ml}$ in a calibrated flask, then $5 \mathrm{ml}$ was neutralized with $5 \mathrm{ml}$ of $20 \%$ sodium carbonate and diluted with water to $25 \mathrm{ml}$ to obtain $100 \mu \mathrm{g} \mathrm{ml}$ and kept protected from sun light in ambient bottle.

Reagent solution: $5 \times 10^{-3} \mathrm{M}$ o-chloranil solution was prepared by dissolving $0.123 \mathrm{~g}$ in absolute ethanol and diluted to $25 \mathrm{ml}$ in a calibrated flask with the same solvent.

Basic solutions: $20 \%$ sodium bicarbonate and $0.01 \mathrm{M}$ sodium hydroxide were prepared by in distilled water. 


\section{Recommended procedure}

Aliquots of the working solution of RCAP $\left(2-65 \mu \mathrm{g} \mathrm{ml}^{-1}\right)$ were transferred into a series of $5 \mathrm{ml}$ calibrated flasks. Then, $0.4 \mathrm{ml}$ of $5 \times 10^{-3} \mathrm{o}-$ chloranil and $0.5 \mathrm{ml}$ of $0.01 \mathrm{M} \mathrm{NaOH}$ were added and the solutions were diluted to the mark with distilled water and kept at room temperature for 5 $\min$. The absorbance was measured at $527 \mathrm{~nm}$ against reagent blank.

\section{Procedure for chloramphenicol assay in capsules and eye drops}

Ten capsules ( $250 \mathrm{mg}$ each) were emptied, pulverized, and dissolved in distilled water with vigorous stirring. The solution was diluted to 1 liter. An aliquot equivalent to $50 \mathrm{mg}$ of chloramphenicol was taken and reduced using zinc and $\mathrm{HCl}$. The solution was filtered, neutralized and subjected to the recommended procedure described above for pure chloramphenicol. For eye drops $(0.5 \%)$, a suitable volume was diluted, and the above procedure was followed.

\section{Results and discussion Spectral characteristics}

The proposed method involves the reduction of chloramphenicol and reaction with o-chloranil reagent in the presence of $\mathrm{NaOH}$ to form a purple colored charge transfer complex having maximum absorption at $527 \mathrm{~nm}$. This wavelength was used for all subsequent measurements. The absorption spectra of the reaction product are shown in Figure 1. The corresponding reagent blank have low absorbance at this wavelength.

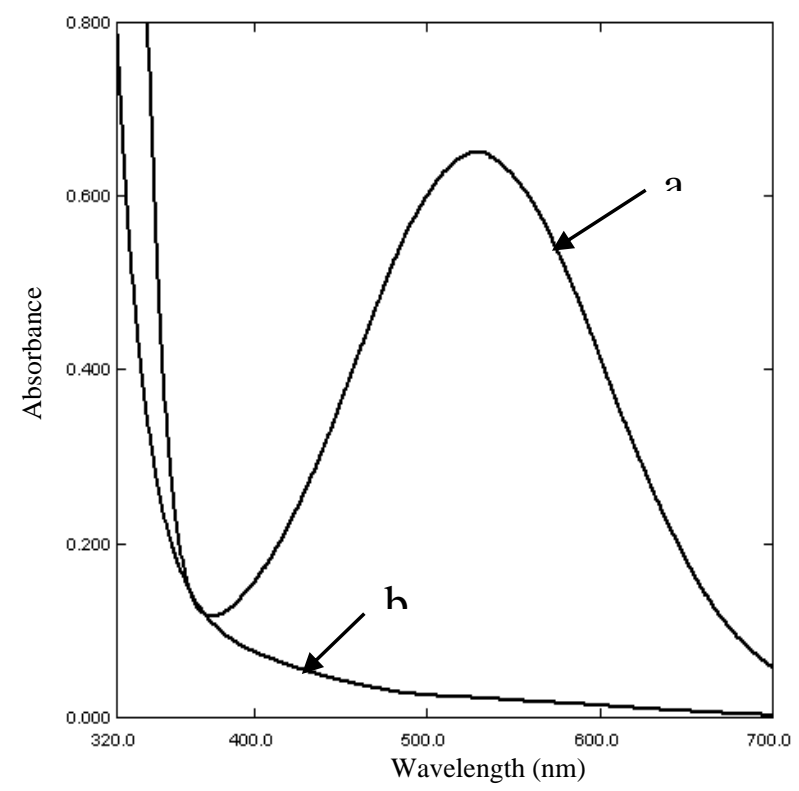

Figure 1: Absorption spectra of (a) RCAP $\left(50 \mu \mathrm{g} \mathrm{ml}^{-1}\right)$ complex with $o-C A$ reagent $\left(5 \times 10^{-3} \mathrm{M}\right)$ against reagent blank and $(\mathrm{b})$ reagent blank against distilled water. 


\section{Optimization of experimental conditions}

The optimum conditions for the color development of the $\mathrm{o}-\mathrm{CA}$ RCAP complex were established by varying the parameters one at a time, keeping the others fixed and observing the effect produced on the absorbance of colored species. The following experiments were conducted for this purpose and conditions so obtained were incorporated in general procedure.

\section{Effect of solvent}

Different solvents such as methanol, ethanol, acetonitrile, acetone and water as medium for the reaction have been tried in order to achieve maximum sensitivity and complex stability, As shown in Table1. It was found that on using water as solvent for chloramphenicol and absolute ethanol as solvent for $o-C A$ in the presence of $\mathrm{NaOH}$ and dilution with the water were gave maximum color intensity. Therefore; these systems of solvents are recommended in this method.

Table 1: Effect of solvents on absorbance of o-CA-RCAP complex

\begin{tabular}{|c|c|c|c|c|}
\hline $\begin{array}{c}\text { RCAP } \\
(20 \mu / \mathrm{ml})\end{array}$ & $\begin{array}{c}\text { o-CA } \\
\text { Dissolved } \\
\text { in }\end{array}$ & $\begin{array}{l}\text { Dilution } \\
\text { by }\end{array}$ & $\lambda_{\max }$ & Absorbance \\
\hline Water & Methanol & Water & 533.5 & 0.238 \\
\hline Water & Methanol & Methanol & 545 & 0.228 \\
\hline Water & Ethanol & Water & 527 & 0.274 \\
\hline Water & Ethanol & Ethanol & - & turbid \\
\hline Water & Acetone & Water & 530 & 0.261 \\
\hline Water & Acetone & Acetone & - & turbid \\
\hline Water & Acetonitrile & Water & 532.5 & 0.231 \\
\hline Water & Acetonitrile & Acetonitrile & 530 & 0.271 \\
\hline
\end{tabular}

\section{Effect of $p H$ and buffer solutions}

The effect of $\mathrm{pH}$ on the absorption of the complex was studied using different $\mathrm{pH}$ values ranged from 2 to12 by using of $0.01 \mathrm{M} \mathrm{HCl}$ and $\mathrm{NaOH}$. It was found that the complex was formed at $\mathrm{pH} 9.2$ by addition of $\mathrm{NaOH}$ (Figure 2). Decrease in absorbance was observed through addition of $\mathrm{HCl}$, which may be attributed to the liberation of hydrogen chloride. Therefore different buffers of $\mathrm{pH} 9.2$ was prepared to examine the sensitivity. A negative effect was observed on the color intensity. 


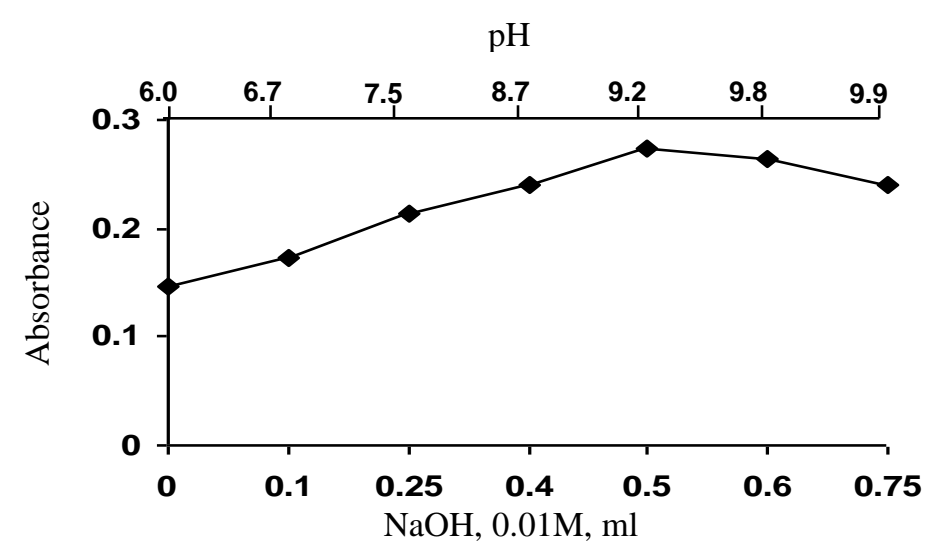

Figure 2: Effect of $\mathrm{pH}$ and $\mathrm{NaOH}$ amount on the absorptio of $20 \mathrm{\mu gml}^{-1}$ RCAP complex with $o-C A$

\section{Effect of bases}

To obtain high sensitivity for the complex, different bases such as sodium hydroxide, potassium hydroxide, sodium carbonate and sodium bicarbonate with fixed volume and a concentration of $0.01 \mathrm{M}$ were examined by addition to a fixed amount of RCAP. It was found that sodium hydroxide gave maximum color intensity (Figure 3), and the optimum amounts of this base were found to be $0.5 \mathrm{ml}$ which was used in the subsequent experiments.

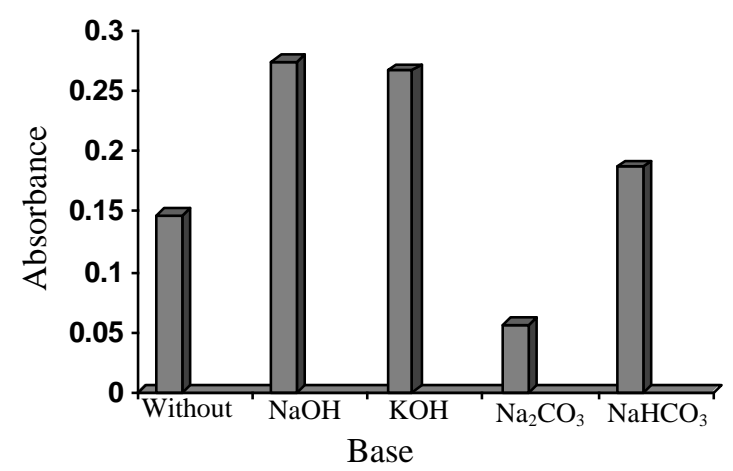

Figure 3 : Effect of Different bases on the intensity of $20 \mathrm{\mu gml}^{-1}$ RCAP complex with $o-C A$

\section{Effect of o-CA concentration}

The effect of changing the $o-C A$ concentration on the absorbance of solution containing a fixed amount of RCAP was studied. It was observed that the absorbance increases with increasing $o-C A$ concentration and reached maximum on using $0.4 \mathrm{ml}$ of $5 \times 10^{-3} \mathrm{M} \mathrm{o-CA}$ (Figure 4). Therefore, this volume of this concentration was used in the subsequent work. 


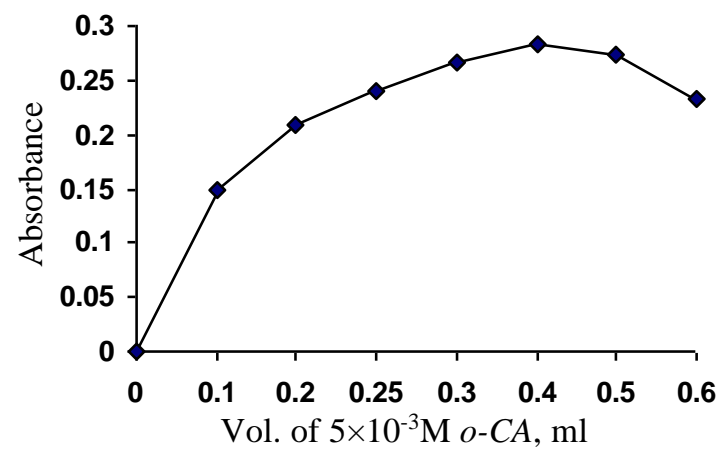

Figure 4: Effect of $0-C A$ reagent concentration on absorbance of $20 \mathrm{\mu gml}^{-1} \mathrm{RCAP}$

\section{Effect of temperature and reaction time}

The reaction time was determined by following the color development at room temperature and in thermostatically controlled water-bath at different temperatures. The absorbance was measured at 5 and 10 minutes intervals against reagent blank treated similarly. It was observed that maximum absorbance and stability was obtained at room temperature $\left(25^{\circ} \mathrm{C}\right)$. It was found that complex gave maximum absorption after $5 \mathrm{~min}$. and remain constant for more than $3 \mathrm{hrs}$ and the color was fading slowly thereafter. Hence, $5 \mathrm{~min}$ at room temperature is recommended for the proposed method.

\section{Effect of surfactant}

Effect of various surfactants including sodium dodecyl sulphate (SDS), cetylperydinum chloride (CPC), cetyltrimethylammonium bromide (CTAB), Tween- 80 and Triton $\mathrm{x}-100$ were tested. It was found that these surfactants decreased the absorbance of solutions.

\section{Effect of order of addition of reactants}

To obtain optimum results the order of addition of reagents should be followed as given under the general procedure, otherwise a loss in color intensity was observed.

\section{QUANTIFICATION}

In order to investigate the range in which the colored complex adhere to Beer's law, the absorbance of the complex was measured at 527 $\mathrm{nm}$ after developing the color by following the general procedure calibration graph for a series of solutions containing increasing amounts of RCAP. The Beer's law limits and molar absorptivity values were evaluated and given in Table 2, which are indicated that the method is sensitive. The linearity was represented by the regression equation and 
the corresponding correlation coefficient for the studied determined drugs by the proposed method represents excellent linearity. The relative standard deviation (RSD) and accuracy (average recovery \%) for the analysis of six replicates of each three different concentrations

for chloramphenicol indicated that the method is precise and accurate. Limit of detection (LOD) are in the accepted range below the lower limit of Beer's law range.

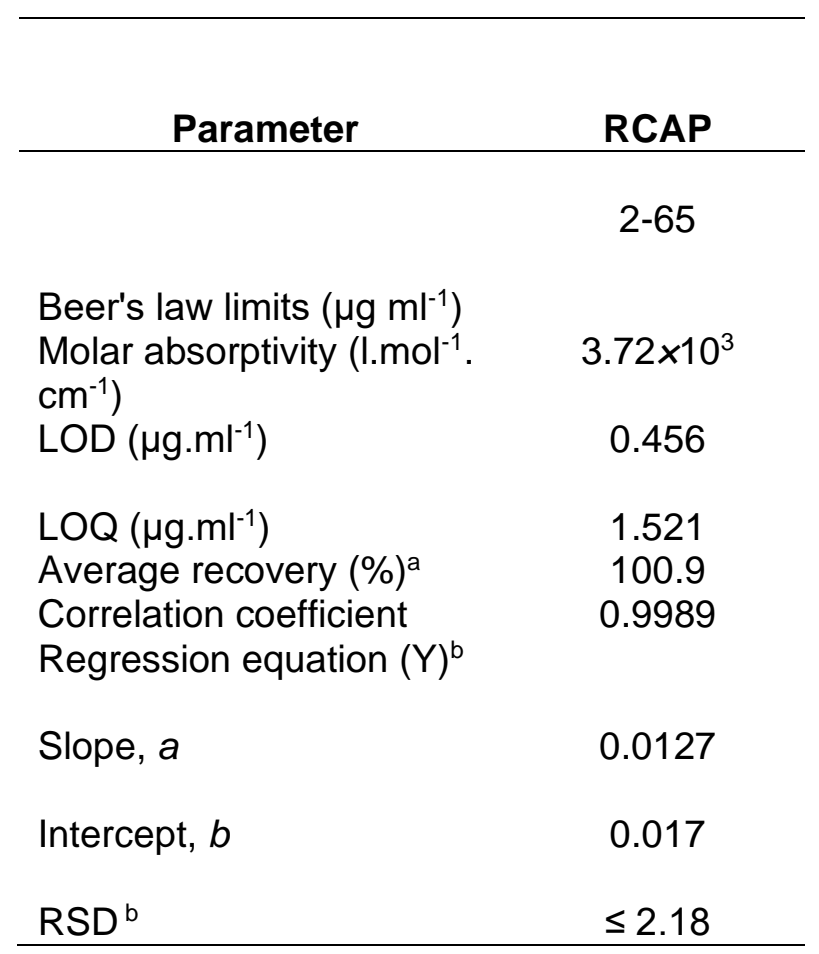

Table 2: Summary of optical characteristics and statistical data for the proposed method

a Average of six determinations.

${ }^{b} Y=a X+b$, where $X$ is the concentration of drug in $\mu \mathrm{g} \mathrm{ml}^{-1}$.

\section{INTERFERENCE}

The extent of interference by some excipients which often accompany pharmaceutical preparations were studied by measuring the absorbance of solutions containing fixed amount of RCAP and various amounts of diverse species in a final volume of $5 \mathrm{ml}$. It was found that the studied excipients did not interfere seriously (Table 3). Slight positive interference was observed in the presence of large excess of excipients. However; an error of $5.0 \%$ in the absorbance readings was considered tolerable. Typical results are given in table 4 . 
Table 3: Effect of excipients for assay of chloramphenicol

\begin{tabular}{|c|c|c|c|c|c|}
\hline \multirow[t]{2}{*}{ Exciepient } & \multicolumn{5}{|c|}{$\begin{array}{c}\text { Recovery } \% \text { of } 20 \mu \mathrm{g} / \mathrm{ml} \text { of chloramphenicol per } \mu \mathrm{g} / \mathrm{ml} \\
\text { Foreign added }\end{array}$} \\
\hline & 20 & 40 & 100 & 200 & 400 \\
\hline Glucose & 98.80 & 100.79 & 101.38 & 99.42 & 102.77 \\
\hline Lactose & 99.22 & 100.57 & 101.30 & 102.77 & 103.74 \\
\hline Arabic Gum & 101.97 & 101.57 & 104.32 & 104.45 & 106.57 \\
\hline $\begin{array}{l}\text { Sodium } \\
\text { chloride }\end{array}$ & 100.00 & 100.79 & 100.95 & 101.30 & 103.67 \\
\hline Sucrose & 100.22 & 101.20 & 98.80 & 101.20 & 100.87 \\
\hline Starch & 100.79 & 100.47 & 100.47 & 101.20 & 101.69 \\
\hline
\end{tabular}

\section{STOICHIOMETRY AND STABILITY CONSTANT}

The molar ratio of the $n-\pi$ charge transfer complex formed between the RCAP and $o-C A$ reagent was investigated by applying the mole ratio and continuous variation (Job's) methods [29]. The results indicated that complex was formed in the ratio of 1:1 (Figures 5). This finding supports that the $n-\pi$ CT complex is formed through amino group. The stability constant $\left(\mathrm{K}_{\mathrm{st}}\right)$ of the complex was determined according to the previous ratio and found $4.2 \times 10^{4} \mathrm{l}$. $\mathrm{mol}^{-1}$. However; the probable reaction mechanism based on the reported method ${ }^{[30]}$ is given in scheme 2 .
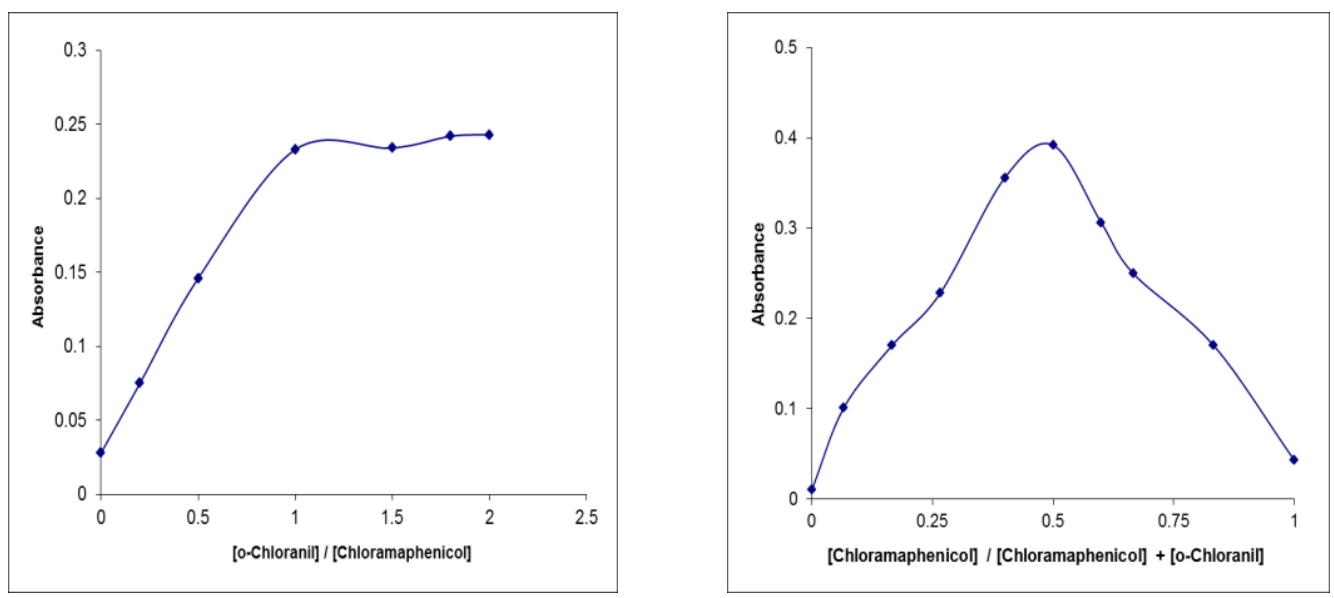

Figure 5: Mole ratio (a) and continuous variations (b) plots for complex of RCAP $\left(1 \times 10^{-3} \mathrm{M}\right)$ and $o-C A\left(1 \times 10^{-3} \mathrm{M}\right)$ under the optimum conditions.

\section{REACTION MECHANISM}

The interaction of RCAP with $o-C A$ in ethanol solvent, was a charge-transfer complexation reaction between the RCAP as n-donor drug and $o-C A$ as $\pi$-acceptor, followed by the formation of a radical anion. Complete electron transfer from the donor to the acceptor moiety took place with the formation of intensely colored radical ions with high molar absorptivity values, (scheme 2) 
<smiles>CC(C)(C)C1(Cl)C(Cl)=C(Cl)C(=O)C(=O)C1Cl</smiles><smiles>O=C(NC(CO)C(O)c1ccc([N+](=O)[O-])cc1)C(Cl)Cl</smiles>

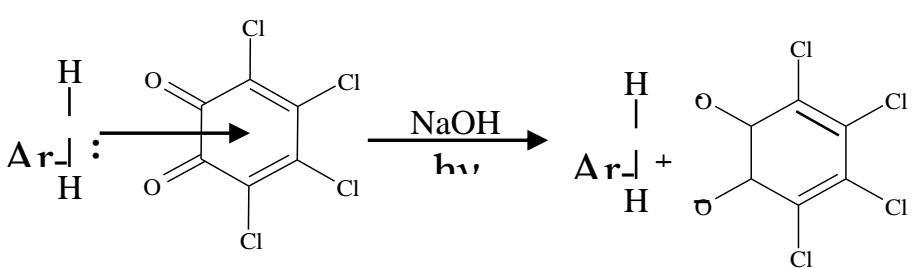

$\mathrm{n}-\pi \mathrm{CT}$ complex

Scheme 2: Probable mechanism for the reaction of $o$-CA with RCAP

\section{ANALYTICAL APPLICATIONS}

The proposed method was successfully applied to determine chloramphenicol in pharmaceutical capsules and eye drops preparations. The obtained results were compared statistically by a Student's $t$-test for accuracy and a variance ratio $F$-test for precision with the official method [7] at the 95\% confidence level with six and four degrees of freedom respectively, as cited in Table 4 . The results showed that the experimental $t$-test and $F$-test were less than the theoretical value ( $t=2.45, F=6.39)$, indicating that there was no significant difference between the proposed method and official method. The proposed method is compared favorably with other reported methods as shown in Table 5.

Table 4: Assay of chloramphenicol in pharmaceutical preparations using the proposed method and comparison with the official method

\begin{tabular}{|c|c|c|c|c|c|c|}
\hline $\begin{array}{l}\text { Procedure } \\
\text { applied }\end{array}$ & $\begin{array}{c}\text { Pharmaceutical } \\
\text { preparation }\end{array}$ & $\begin{array}{c}\text { Drug } \\
\text { amount } \\
\text { present } \\
\left(\mu \mathrm{g} * \mathrm{ml}^{-1}\right)\end{array}$ & $\begin{array}{c}\text { Recoverya } \\
(\%)\end{array}$ & $\begin{array}{l}\text { Drug } \\
\text { content } \\
\text { found } \\
\text { (mg) }\end{array}$ & $\begin{array}{c}\text { Average } \\
\text { recovery } \\
\quad(\mathrm{mg})\end{array}$ & $\begin{array}{c}\text { Certified } \\
\text { value } \\
\text { (mg) }\end{array}$ \\
\hline \multirow{2}{*}{$\begin{array}{l}\text { Proposed } 0-C A \\
\text { method }\end{array}$} & Capsule & $\begin{array}{l}15 \\
35 \\
50 \\
\end{array}$ & $\begin{array}{c}99.00 \\
101.13 \\
103.40\end{array}$ & $\begin{array}{l}244.0 \\
255.2 \\
250.5 \\
\end{array}$ & $\begin{array}{c}249.9 \\
(1.97,1.05)^{\mathrm{b}}\end{array}$ & 250 \\
\hline & Eye drops & $\begin{array}{l}15 \\
35 \\
50\end{array}$ & $\begin{array}{l}99.60 \\
95.95 \\
98.99\end{array}$ & $\begin{array}{l}0.515 \\
0.492 \\
0.494\end{array}$ & $\begin{array}{c}0.50 \% \\
(2.12,1.76)\end{array}$ & $0.5 \%$ \\
\hline \multirow{2}{*}{$\begin{array}{c}\text { British } \\
\text { Pharmacopoeia }\end{array}$} & Capsule & 10 & 99.2 & 248 & - & 250 \\
\hline & Eye drops & 10 & 101.8 & 0.509 & - & $0.5 \%$ \\
\hline
\end{tabular}


Table 5: Comparison of spectrophotometric methods for RCAP determination

\begin{tabular}{|c|c|c|c|c|}
\hline \multirow{2}{*}{$\begin{array}{l}\text { Analytical } \\
\text { parameters }\end{array}$} & \multirow{2}{*}{$\begin{array}{l}\text { Present } \\
\text { method o- } \\
\text { Chloranil }\end{array}$} & \multicolumn{3}{|c|}{ Literature method } \\
\hline & & p-Chloranil [27 ] & $\underset{[27]}{p-F l o u r a n i l}$ & TCNQ ${ }^{[28]}$ \\
\hline$\lambda_{\max }(\mathrm{nm})$ & 527 & 342 & 350 & 464 \\
\hline $\mathrm{pH}$ & 9.2 & 9.0 & 9.0 & 7.5 \\
\hline Temp. $\left({ }^{\circ} \mathrm{C}\right)$ & $25^{\star}$ & 40 & 45 & 40 \\
\hline Development(min) & 5 & 50 & 40 & 20 \\
\hline $\begin{array}{l}\text { Stability } \\
\text { period(min) }\end{array}$ & $>3 \mathrm{hrs}$ & 40 & 30 & 25 \\
\hline Beer's law $(\mu \mathrm{g} / \mathrm{ml})$ & $2-65$ & $0.4-14$ & $0.2-14$ & $0.15-32$ \\
\hline $\begin{array}{l}\text { Molar absorptivity } \\
\left(\text { I.mol-1. } \mathrm{cm}^{-1}\right)\end{array}$ & 3720 & 12560 & 14570 & 27570 \\
\hline Recovery (\%) & 100.90 & 98.4 & 100.72 & 99.67 \\
\hline $\mathrm{RSD}(\%)$ & 0.91 & 0.46 & 0.49 & 0.91 \\
\hline
\end{tabular}

${ }^{\star}$ Room temperature

\section{CONCLUSION}

The proposed method is sensitive (trace amounts can be determined), accurate (average recovery range 100.9\%), precise (RSD $\leq$ 2.18) and simple since it does not need neither temperature control nor solvent extraction step. Analysis of authentic samples containing chloramphenicol showed no interference from common additives and auxiliary substances in general. The statistical analysis is in good agreement with those of the official British Pharmacopoeia and other reported methods. Hence, this method could be considered for the determination of chloramphenicol both in pure form and in pharmaceutical preparations.

\section{REFERENCES}

1) Database of National Toxicology Program (NTP), U. S. Department of Health and Human Services, Substance Profiles Report on Carcinogens, 11th ed., http://ntp.niehs.nih.gov/ntp/roc/eleventh/profiles/s032chlo.pdf.

2) P. A Guya et al,. J.Chromatogr.,1054, 365-371,(2004).

3) Impens, S.; Reybroeck, W., Vercammen, J., Courtheyn, D. ; Ooghe, S. ; De Wasch, K.; Smedts, W.; De Brabander, H., Anal. Chim. Acta, 483, 153-163, (2003).

4) Agüí, L.; Guzmán, A.; Yáñez-Sedeño P.; Pingarrón, J. M., Anal. Chim. Acta, 461, 65-73, (2002).

5) Viñas, P.; Balsalobre, N.; Hernández-Córdoba, M., Anal. Chim. Acta, 2006, 558,11-15.

6) Shakila, R. J.; Vyla, S. A.; Kumar, R. S.; Jeyasekaran, G.; Jasminem, G. I., Food Microbio., 23, 47-51, (2006).

7) British Pharmacopoeia, HM Stationery Office, London, Vol. I, pp.1553 - 1556, (1998). 
8) United States Pharmacopoeia (XXIV Ed.), USP Convention Inc., Rockville, pp. 373-376, (2000).

9) Munns, R.K.; Holland, D.C.; Roybal, J.E.; Storey, J.M.; Long, A.R.; Stehly, G.R. and Plakas, S.M., J. Assoc. Anal. Chem., 77, 596 - 601, (1994).

10) Mc Niven, S.; Kato, M.; Levi, R., Yano K. and Karube, I., Anal. Chim. Acta., 365, 69-74, (1998).

11) Pentari, J. G.; . Efstathiou, C. E, Anal. Chim. Acta, 153, 161 - 168, (1983).

12) Lindino, C. A.; Bulhoes, L. O. S., Braz. Chem. Soc., 15,. 178-182, (2004).

13) David, V. Saez, R. M.; Mateo, J. V.; Martinez, J., Analyst, 125, 1313 1319, (2000).

14) Jayaram, B.; Mayanna, S. M., Talanta, 30, 798 - 800, (1983).

15) Dessouky, Y. M.; Toth, K.; Pungor, E., Analyst, 95, 1027 - 1031, (1970).

16) Morales, A.; Toral, M. I.; Richter, P., Analyst, 109,633- 636, (1984).

17) Bautista, J. A.G.; Mateo, V. G.; Martinez, J., Anal. Chim. Acta, 404,141$150,(2000)$.

18) Montero, R.; Gallego, M.; Valcarcel, M., Talanta, 37, 1129 - 1132, (1990).

19) Mason, E. 0.; Kaplan, S. L.; Baker C. J.; Ritter, D. A., Ant. Agen. Chem., 15, 544-546, (1979).

20) Hassan, S. S. M.; Eldesouki, M. H., Talanta, 26, 531-537, (1979).

21) Devani, M.; Shishoo, C. J.; Doshi, K. J.; Shah, A. K., J. Assoc. Anal. Chem., 64, 557-563, (1981).

22) Hiremath, R. C.; Mayanna, S. M., Microchim. Acta, 2, 175 - 179, (1984).

23) Naik, S. D.; Nagaraja, P.; Yathirajan, H. S.; Hemanthakumar, M. S.; Mohan, B. M., Pharm. Chem. J., 40,576-581, (2006).

24) Abdel Hamid, M. E.; Abuirjeie, M.A., J. Pharm. Biomed. Anal., 5,577 583, (1987).

25) Morelli B., J Pharm Biomed Anal. 5, 577-583, (1987).

26) Eboka, C. J.; Smart J.; Adelusi, S. A., Trop. J. Pharm. Res., 2, 215-221, (2003).

27) Jarallah S.M., "Development of spectrophotometric methods for determination of drug nitrogen compounds", M.Sc. Thesis, Mosul university, (1998).

28) Hassan M. A., "Development of spectrophotometric method for the determination of drug compounds in pharmaceutical preparations using $7,7^{\prime}, 8,8^{\prime}$-tetracyanoquinondimethane", Ph. D. Thesis, Mosul University, (2008).

29) Hargis, L.G.. "Analytical Chemistry, Principles and Techniques", Prentice- Hall Inc., New Jersey, pp. 424- 427, (1988).

30) Alzoman N. Z. et al., Analytical study for the charge-transfer complexes of rosuvastatin calcium with $\pi$-acceptors, Molecules, 18, 7711- 7725, (2013). 